\title{
Growth Patterns of Crude and Purified Myc. Lepraemurium in Subcutaneous Tissues of Mice
}

\author{
YutAKa MITSUFUJI and Masahiro NAKAMURA \\ Department of Microbiology, Kurume University School of Medicine, Kurume, Japan
}

The growth patterns of Myc. lepraemurium that followed inoculation of crude and purified bacilli into subcutaneous tissues of mice were observed by means of the spread tissue preparations which was described by Kawaguchi.

The growth patterns of the bacilli in mice were divided into two types; (1) the type of inoculation of crude bacilli; i.e. the growth of bacilli at the extracellular and intracellular sites. (2) the type of inoculation of pruified bacilli; i.e. only intracellular growth of bacilli. The former type includes the cases of inoculations of purified bacilli into dd-mice, inoculations of crude bacilli into $\mathrm{C}_{3} \mathrm{H}$-mice, and inoculation of bacilli purified from rat leproma, containing subcutaneous tissues of $\mathrm{C}_{3} \mathrm{H}$-mice and rat. On the other hand, experimental results obtained in the cases of inoculation of crude bacilli into dd-mice, and of bacilli purified from rat leproma, containing the subcutaneous tissues of rabbits and guinea-pigs, were belonged to the latter. 


\title{
精製鼠癩菌と粗鼠癩菌とのマウス体内における増殖態度*
}

\author{
光藤 坦 -中村昌弘 \\ 久留米大学医学部微生物学教室細菌学講座 (指導: 中村昌弘教授)
}

（受付 1967 年 3 月 4 日）

マウスの個体，並に系統によって鼠癩菌の感受性が著 しく異ることは周知のととであるが，乙の原因は不明で ある。恐らく人癩の感染に於ても，ヒト間の個体差によ って, 人癭の発症が左右されている感がないでもない。 人癩菌の動物移植実験に際しても，最近 Shepard ${ }^{12}$ によ って人癩菌のマウス足躘内增殖が報告されているとはい え, 人以外の動物に人癩同様の病変を再現しうる可能性 は今のと乙ろ乏しい。乙の原因が人癩菌に対する他動物 の反応，即ち免疫の短期間仿於る獲得之考えるむきもあ る。

そこで，こてでは鼠癩菌を用いて，それを精製した状 態，即ち感染組織をできるだけ除去した状態でマウスに 感染させた場合とそうでない状態で感染させた場合とで マウス内に於る鼠癩菌の增殖样相が異るか否かを検討 し，人癩並に鼠㿗の動物実験の一資料とした。乙の実験 を行うに当って，とてに誠に好箇の実験方法がある。そ れは川口等2,3) によって開発された伸展標本法であり， これを用いて鼠癩菌のマウス体内に於る增殖像を観察し た。

\section{実験材料並に方法}

供試鼠癩菌：マウス (dd 系) 並にラット (Wistar 系) 皮下に接種され，3〜6ケ月後に生じた熊本株鼠瀬腫を 用いた。普通は乙れを滅菌乳鉢でよくすりつぶし, 生塩 水で約10\%の乳剂にし，低遠心した上清を用いた。

鼠癩菌の精製法 : 中村等) によって前に報告したトリ プシンと Desoxycholate による方法によって鼠瀬菌を感 染組織より分離し, 精製した。

供試動物: $\mathrm{dd}$ 系並に $\mathrm{C}_{3} \mathrm{H}$ 系マウス

增殖観察用の標本作製法 : 川口等2,3) の方法による伸 展標本法を用いた。

* 本研究は文部省科学研究費綜合研究「癩菌の動物 移植」によった。

\section{実 験 成 績}

I. 粗並に精製鼠癩菌のマウス皮下組織における增殖 態度。

粗並に精製鼠瀬菌乳剂をマウスの皮下へ接種して, “0”，5，10，15及び20日每にその部の伸展標本を作製 して四癩菌の増殖像を観察した。接種部位は接種位置の 混乱をさけるために峌耳間の皮下を選んだ。

接種材料は下記のスケジュールに従った。

1) 100 倍稀釈粗鼠癩菌菌剂

2）100倍稀釈精製鼠瀬菌乳剂

3 ） 50 倍稀䣋精製鼠瀬菌乳剂化等量の正常マウス皮下 組織乳剂を加えたもの。

4) 加热粗鼠瀬菌乳剂

このような接種材料を用いると粗鼠瀬菌乳剂接種群で は細胞への菌のとりてみが良くなく, 細胞外にも多数の 菌を認めるのに反して, 精製鼠瀬菌乳剂接種群では細胞 内への菌のとりとみが極めて良好で, 菌の localization が細胞内に限られている。精製菌にマウス正常組織を混 和して接種した群では, これに対して, 粗鼠瀬乳剂を接 種した所見に近い像を示していた。加熱鼠瀬菌接種群で は全般的に菌が減少するためか, 細胞内及び外の菌数が 少いが接種後15日より細胞内菌のみを見る所見になり細 胞外の菌が認められなくなる。ただての場合は細胞内の 菌形が接種後20日になっても延長を来さず，硬い形態の 集合として認められる。乙れらの様相を第 $1 ， 2 ， 3$ 及 び4の写真に示し，その代表的所見を第 1 図にまとめ た。

II. ラット鼠癩菌乳剂の dd 系マウス及び $\mathrm{C}_{3} \mathrm{H}$ 系マ ウスにおける增殖態度。

ラット皮下に実験的に感染させて生じた鼠癩腫より作 製した粗乳剂を dd 系マウスと $\mathrm{C}_{3} \mathrm{H}$ 系マウスに接種し てその増殖態度を観察した。その所見は写真 5 及び 6 に 示すように， dd 系マウス体内でのラット・レプローム 
粗ソライ菌と精製ソライ菌のマウス体内増殖

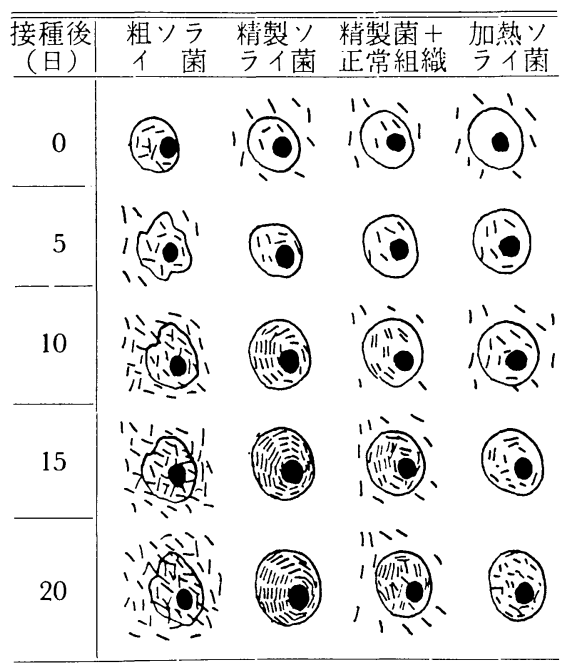

菌の增殖態度はマウス・レプローム内の粗菌乳剂を dd 系マウスに接種した埼合によく似て, 細胞の菌のとりこ みが悪く, 細胞外に多数の菌が存在していた。てれに反 して, ラット・レプローム菌を $\mathrm{C}_{3} \mathrm{H}$ 系マウスに接種し た場合の増殖像は精製鼠瀬菌を dd 系マウスに接種した 所見に酷似し, 茵は細胞内に完全にとり込まれ, 細胞内 で綺麗な配列をなして增歹している像が涩められた。従 って $\mathrm{C}_{3} \mathrm{H}$ 系マウスの細胞は鼠癩菌を選択的に食菌する 能力をもっているものと瑟われる。

III. 精製ラット鼠瀬菌乳剂に他種動物皮下組織を添加 したものを接種した場合の增殖像。

ラット皮下鼣癩腫を精製して菌を分離して精製鼠瀬菌 としたものに等量の生塩水， $10 \% \mathrm{C}_{3} \mathrm{H}$ 系マウス皮下組 織乳剂，10\%ラット皮下組織乳剂，10\%家克皮下組織乳 剂及びモルモット皮下組織乳剂を加えたものを dd 系マ ウスに接種してその増殖像を観察した。

その所見を総括すると, 次の 2 群に分れた。（1）精 製鼠癩菌十生塩水, 精製鼠癩菌 $+10 \% \mathrm{C}_{3} \mathrm{H}$ 系マウス皮 下組織乳剂, 精製鼠癩菌 $+10 \%$ ラット皮下組織乳剂の 3 群は細胞内に菌がよくとり込まれ, 細胞外の菌が少く, 精製鼠癩菌をマウスへ接種した増殖像に酷似した。（2） 精製鼠癩菌 $+10 \%$ 家婜皮下組織, 及び精製鼠癩菌 $+10 \%$ モルモット皮下組織乳剂の 2 群は粗鼠癩菌乳剂をマウス に接種したの之同じ増殖像を示した。この所見からみれ ば鼠癩菌に感受性ある $\mathrm{C}_{3} \mathrm{H}$ 系マウス及びラットの皮下 組織は鼠癩菌の細胞内侵入と增殖をさまたげないか, 或
は発育促進作用があるように思われるし，逆に家鬼とモ ルモットの皮下組織は鼠癩菌の細胞内侵入と增殖を阻止 する作用があるように考えられる。

\section{考察}

川口5) は鼠瀬の病型を 2 型に分けた。即ち良性鼠癩型 と悪性鼠瀬型であるが, 前者は $\mathrm{C}_{57} \mathrm{BL} / 6$ 系マウスに鼠 瀬菌が接種された場合の所見であり，結節は早期に触れ るが, 決して大きくならないもの, 後者は $\mathrm{C}_{3} \mathrm{H}$ 系マウ スに接種された場合の所見で, 結節の触れる時期は遅い が，遂には大結節となるものである。

川口吕は更に伸展標本法を用いて $\mathrm{C}_{57} \mathrm{BL} / 6$ 系マウス に鼠癩菌が接種された場合の増殖像と $\mathrm{C}_{3} \mathrm{H}$ 系マウスに 接種された場合の增殖像とを比較しているが，早期増殖 像では，両者の間に差がなく，長期観察によってその差 がつけられることを認めて, 同氏の良性型病変を作るマ ウスは鼠癩菌に対して強い免疫を作る性質を先天的にも つものであるという自説に支持を自ら与えている。

しかし，乙こで述べた実験成績によると粗鼠癩菌乳剂 と精製鼬癩菌剂とを dd 系マウス皮下に接種した場合で は, 明らかに壃殖像の差異が認められる。即ち前者では 菌は単核細胞内に雑然と侵入し, 細胞外にも多数の菌が 認められるが, 後者では細胞外藏は少く, 細胞内に入っ た菌は整然と配列し，その中で增殖する像が認められ る。接種後の時間を追うと前者では Globi の形成が少 く, 且つ遅れるのに反して, 後者では早期より Globi と して鼠癩菌が発育し菌数も極めて多い。

てれを考祭するに, 前者が良性型鼠癩に似て, 後者が 悪性型鼠瀬に酷似している。

前者に属する実験群としては（1）粗マウス鼠瀬菌乳 剂を dd 系マウスに接種した場合，（2）ラットに生じた レプローム乳郕を dd 系マウスに接種した場合，（3） 精製ラット・レプローム鼣癩菌乳剂に家鬼及びモルモッ ト皮下組織乳剂を加えたものを dd 系マウスに接種した 埸合。

後者に属する悪性鼠䫅像を呈する実験群としては（1) 精製マウス鼠癩菌乳剂を dd 系マウスへ接種した場合, （2）ラットレプローム乳剤を $\mathrm{C}_{3} \mathrm{H}$ 系マウスへ接種し た場合，（3）精製ラットレプローム乳剂に生塩水, $\mathrm{C}_{3} \mathrm{H}$ 系マウス皮下組織乳剂, 及びラット皮下組織乳剂 を泥和して dd 系マウスへ接種した場合である。

以上のてとから考察されることは，鼠癩の発症が良性 に進む場合と覀性に進展する場合の差は接種菌を受ける 似の反応性にあるものと思われるが，その反応を惹起す 
る物質は，鼠癩菌をとりまく組織であって菌体そのもの ではなかろうと思われる。将来この点,なお詳細な研究 を必要とするが, 以上の所見は鼠癩の発症, ひいては人 癩の発症機作に奇与するものと思われる。

\section{結 論}

粗製鼠瀬菌乳剂と精製鼠瀬菌乳剂とをそれぞれ，マウ ス皮下に接種して伸展標本によりその後の増曻像をみる と次の 2 型に分れる。

（1）単核細胞により極めてよく食藏され，細胞外菌 の存在が少く恐らく直ちに Globi として伸展するもの。

（2）单核細胞によく食菌されず，組織反応が掏く菌 は細胞外にも多数認められ雑然たる食菌像を認めるも の。

（1）はマウス・レプローム精製菌接種及びラット・レ プローム菌が $\mathrm{C}_{3} \mathrm{H}$ 采マウスへ接種された場合, 並にラ ット・レプローム精製菌に $\mathrm{C}_{3} \mathrm{H}$ 系マウス或はラット・ 皮下組織を添㧈したものを接種した埸合にも思られ， （2）はマウス・レプローム粗製菌及びラット・レプロ
一ム菌が dd 系マウスへ接種された坫合亚にラット・レ プローム精製菌に家克或はモルモット皮下組織を添加し たものを接種した場合にも几られる。

$$
\text { 文献 }
$$

1) Shepard, C.C.; The experimental disease that follows the injection of human leprosy bacilli into foot-pat of mice. J. Exper. Med., 112, 445-454, 1960.

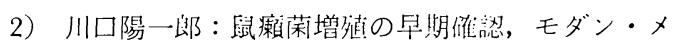
ディア, 10, 380-386, 1964.

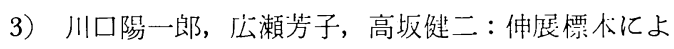
る鼠瀬菌增殖の早期倠㤠, レプラ，33，276-282, 1964.

4）中忖晶弘, 上野由忘：鼠瀬菌の簡便且つ無菌的集 菌法, 日本細菻学雑誌, 18, 75-75, 1963.

5）川口陽一郎：决験鼠癩の病型分類について，レプ ラ, 28, 378-390 1959 . 
光 藤 - 中 村 論 文 附 図

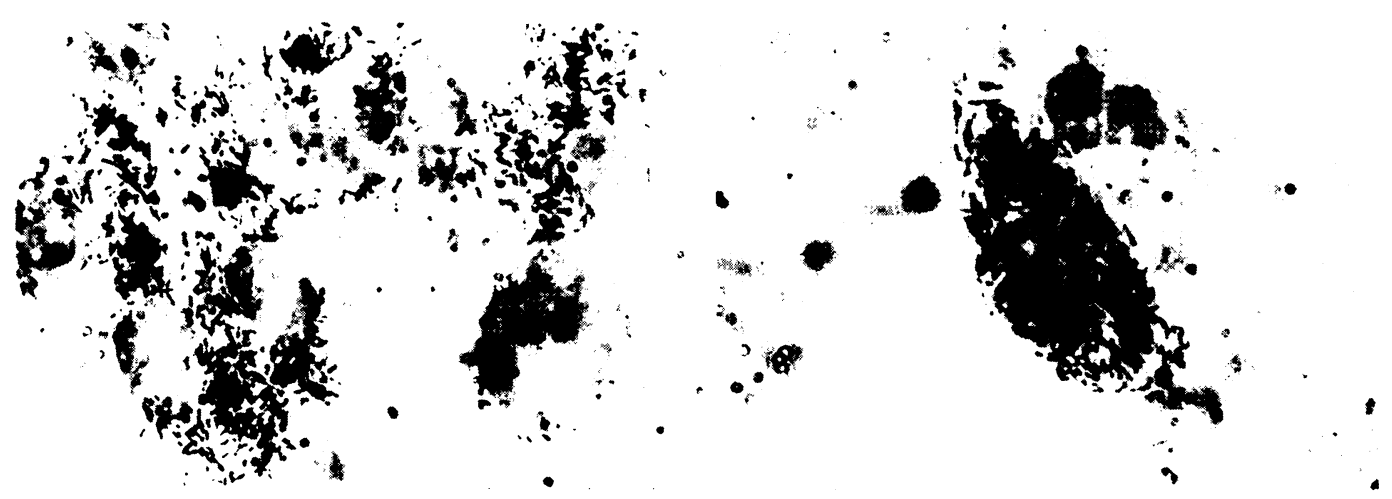

写真 1 粗鼠攋菌乳剂を $\mathrm{dd}$ マウス皮下に接種した伸 写真 2 精製鼠疬菌乳剂を $\mathrm{dd}$ マウス皮下に接種した 展標本（按喠後10日目, $1000 \times$ 拡大）仲展㯲本（揬種後10月目, 1000×拡大）

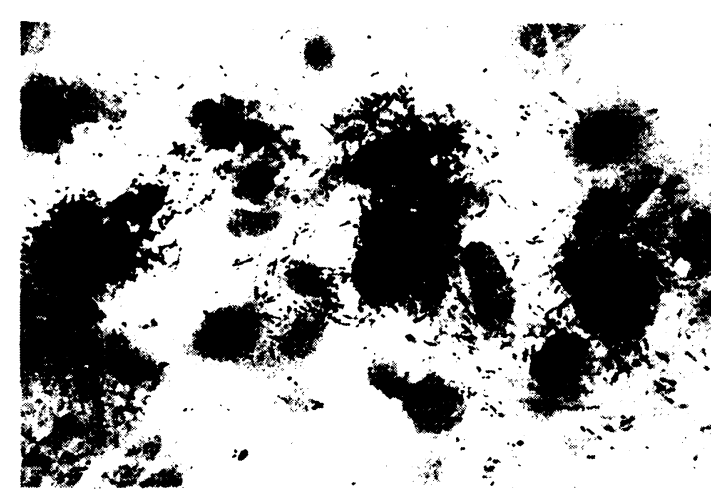

写真 3 同上接種後 20 日目, $700 \times$ 拡大

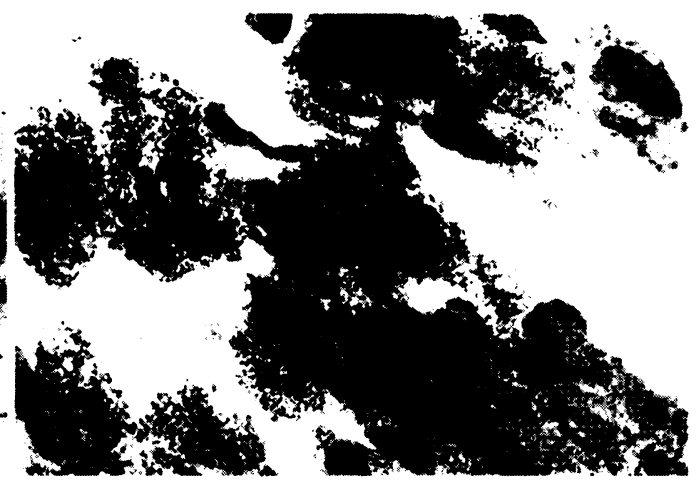

写真 4 同上接種後 20 日目, $700 \times$ 拡大
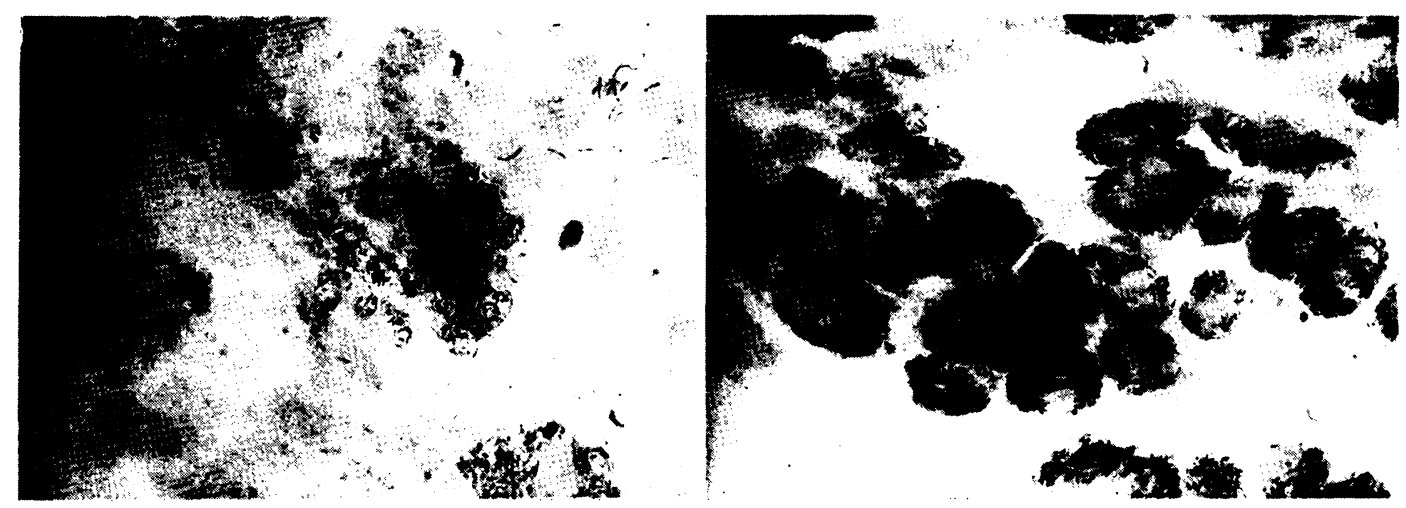

写真 5 ラット・レプローム菌を dd マウスに接種し 写真 6 ラット・レプローム䒩を $\mathrm{C}_{3} \mathrm{H}$ マウスに按種 た伸情標本, $700 \times$ 拡大 